\title{
Active learning for middle school based on information technology in SMA Negeri 1 Dolok Batu Nanggar
}

\author{
T.J. Marpaung ${ }^{1 *}$, Dewi Sartika br. Ginting ${ }^{2}$, Andy Candra ${ }^{3}$, J.L. Marpaung ${ }^{1}$ \\ ${ }^{1}$ Departments of Mathematics, Faculty of Mathematics and Natural Science, Universitas \\ Sumatera Utara, Medan, Indonesia \\ ${ }^{2}$ Departments of Computer Science, Faculty of Computer Science and Information \\ Technology, Universitas Sumatera Utara, Medan, Indonesia \\ ${ }^{3}$ Departments of Chemistry, Faculty of Mathematics and Natural Science, Universitas \\ Sumatera Utara, Medan, Indonesia \\ *Email: tj.marpaung@usu.ac.id
}

\begin{abstract}
After the millennium era, with the rapid development of information technology, changes in business patterns also increased sharply. This is what is called the era of disruption. IT technology has also penetrated the world of education, both in management and in learning methods. In the world of education, now the learning method does not only use conventional methods such as from textbooks and explanations from teachers, but also with effective and efficient learning methods by utilizing information technology. An example is multimedia-based learning media. Community service is one way that can be used to carry out information technology socialization. Community service that will be carried out in this research is entitled Utilization of Information Technology in the Implementation of Active Learning in SMA Negeri 1 Dolok Batu Nanggar in Facing the Era of the Industrial Revolution 4.0, with the aim of helping teachers in a more interesting interactive and fun mathematics learning process, because In general, junior high school students have used a lot of telecommunications devices equipped with various kinds of multimedia. The learning application that is built includes material, exercises and tests, in accordance with applicable competency standards. Furthermore, training will be given to several senior high schools, as a provision on how to prepare and use this learning system application so as to increase student motivation and ultimately increase student achievement and improve the quality of education.
\end{abstract}

Keyword: Technology, E-learning, School

\begin{abstract}
Abstrak
Pasca era millennium, dengan perkembangan teknologi informasi yang cukup cepat, perubahan pola bisnis juga meningkat tajam. Ini yang dinamakan era disrupsi. Teknologi IT juga telah merambah dunia Pendidikan, baik dalam manajemen juga metode penmebalajaran. Dalam dunia pendidikan kini metode pembelajaran tidak hanya menggunakan metode konvensional seperti dari buku-buku pelajaran dan penjelasan dari guru saja, namun juga dengan metode pembelajaran yang efektif dan efisien dengan memenfaatkan teknologi informasi. Sebagai contoh adalah media pembelajaran yang berbasis multimedia. Pengabdian pada masyarakat merupakan salah satu cara yang dapat dipakai untuk melaksanakan pemasyarakatan teknologi informasi. Pengabdian kepada masyarakat yang akan dilakukan pada penelitian ini berjudul Pemanfaatan Teknologi Informasi Dalam Pelaksanaan Pembelajaran Aktif Di Sekolah SMA Negeri 1 Dolok Batu Nanggar Dalam Menghadapi Era Revolusi Industri 4.0, dengan tujuan membantu guru-guru dalam proses pembelajaran matematika yang lebih menarik interaktif dan menyenangkan, karena secara umum siswa sekolah menengah pertama telah banyak menggunakan alat telekomunikasi yang dilengkapi dengan berbagai macam multimedia. Aplikasi pembelajaran yang dibangun mencakup materi, latihan dan test, sesuai dengan standart kompetensi yang berlaku. Selanjutnya akan diberikan pelatihan pada beberapa sekolah menengah atas, sebagai pembekalan bagaimana menyiapkan dan menggunakan aplikasi sistem pembelajaran ini sehingga mampu meningkatkan motivasi belajar siswa dan akhirnya meningkantkan prestasi siswa seta meningkatkan mutu pendidikan.
\end{abstract}

Kata Kunci: Teknologi, Pembelajaran Daring, Sekolah 


\section{PENDAHULUAN}

Secara umum siswa Sekolah Menengah Atas memandang pelajaran matematika adalah pelajaran yang sulit dan membosankan. Selain siswa, guru juga mengalami kesulitan dalam menyampaikan materi, diantaranya keterbatasan waktu dalam menyampaikan materi yang cukup banyak, dan kurangnya ketertarikan siswa belajar matematika apabila menggunakan metode pembelajaran konvensional seperti dari buku pelajaran dan penjelasan dari guru saja. Oleh karena itu perlu diusahakan dalam proses pembelajaran matematika harus lebih menarik lebih interaktif dan menyenangkan.

Dalam hal mencari solusi untuk mengatasi masalah tersebut, sehingga dapat meningkatkan minat belajar dan prestasi belajar siswa pada semua pelajaran. Dalam kegiatan belajar mengajar ketidakjelasan dan banyaknya materi yang disampaikan dapat dibantu dengan menghadirkan media sebagai perantara. Kerumitan bahan pelajaran dapat disederhanakan dengan bantuan media, karena media dapat mewakili apa yang kurang mampu disampaikan melalui kata-kata atau kalimat. Oleh karena itu dalam rangka membantu meningkatkan mutu pendidikan dan pengajaran matematika khususnya, maka perlu memanfaatkan perkembangan teknologi komputer.

Dalam dunia komputer dikenal istilah animasi. Animasi merupakan salah satu bagian grafika komputer yang menyajikan tampilan yang sangat atraktif. Pemanfaatan animasi dapat ditujukan untuk similasi, menarik perhatian pemakai computer pada bagian tertentu pada layar, menampilkan keluaran program dengan gambar-gambar yang menarik dibandingkan dengan sederetan angka atau huruf. Dengan adanya aplikasi ini diharapkan dapat memudahkan dam menyenangkan dalam memahami dan mempelajari materi yang diberikan.

Penggantian sistem ini diharapkan dapat memberikan informasi yang akurat, menghemat biaya dan waktu, sehingga dalam proses belajar mengajar seluruh siswa dapat mengerti materi pelajaran tersebut. Begitu juga perancangan animasi ini dapat memberikan motivasi terhadap siswa dalam hal pembelajaran matematika khususya masalah bangun bidang dan ruang.

Kemajuan teknologi komputer dapat membantu seluruh aspek kehidupan manusia. Permasalahannya belum banyak sekolah dasar yang mempunyai media pembelajaran yang berbasis multimedia khusurnya matapelajaran matematika. Dan banyak siswa yang merasa jenuh dengan sistem pembelajaran yang monoton, apalagi pelajaran matematika yang mempunyai materi cukup banyak. Dengan pertimbangan ini pengusul ingin mernerapkanpengetahuan dan teknologi dengan mengadakan pembuatan dan tutorial media pembelajaran matematika sehinggadapat meningkatkan pemahaman dan menarik minat belajar siswa sertta membantu meningkatkan mutu pendidikan dan pengajaran matematika

\section{METODE PELAKSANAAN}

Kegiatan ini akan dilaksanakan pada kurun waktu Bulan Juni sampai dengan Bulan November dengan memberikan pelatihan bagi guru dan siswa/i SMA Negeri 1 Dolok Batu Nanggar dengan tujuan, guru dapat melaksanakan kegiatan belajar mengajar menggunakan metode pembelajaran aktif berbasis teknologi infomasi. Pelaksana pengabdian akan memberikan pelatihan tentang penyiapan Rencana Proses Pembelajaran berbasis Pembelajaran Aktif. Selanjutnya juga diberikan pelatihan Pembuatan Bahan Ajar yang berbasis Metode Pembelajaran Aktif dengan menggunakan Teknologi Informasi, baik menggunakan Power Point maupun penyiapan bahan berbentuk video pembelajaran. Untuk keberlanjutan dari pelatihan yang diberikan, mitra akan diberikan perangkat komputer, sehingga metode pembelajar aktif di kelas dapat diteruskan.

Pelaksanaan Pengabdian ini akan dilakukan dalam dua tahapan besar, yaitu:

1. Pelatihan Penyiapan Rencana Proses Pembelajaran dan Pembuatan Bahan Ajar berbasis Teknologi Informasi.

2. Pelatihan kegiatan belajar mengajar secara Daring 
Metode yang akan dilakukan pada pelaksanaan pengabdian ini adalah :

1. Mendapatkan data yang berupa informasi yang diambil dari buku atau kurikulum pelajaran matematika khusus materi yang akan dibuat aplikasi pembelajaran nya.

2. Melakukan identifikasi bagaimana membuat agar materi yang dikaji menjadi lebih mudah dipelajari oleh siswa SMA.

3. Untuk menarik minat belajar siswa pada materi ini, akan dibuat aplikasi pembelajaran yang materinya dikemas seefisien mumgkin, sehingga siswa dapat berinteraksi dengan aplikasi tersebut.

4. Melakukan perancangan aplikasi pembelajaran, mulai dari membuat tampilan aplikasi, penyusunan materi, latihan dan soal.

5. Setelah perancangan rampung dan diperoleh hasil yang maksimal, maka dilakukan pembagian aplikasi ini ke sekolah dan membuat pelatihan /workshop kepada guru matematika atau siswa.

\section{HASIL DAN PEMBAHASAN}

Ketua Tim pengabdian USU memaparkan segala kontribusi dan solusi yang akan diberikan oleh perguruan tinggi khususnya USU dalam membekali sekolah di dalam menghadapi tantangan revolusi industri 4.0 terutama dalam hal mengahadapi perubahan pembelajaran akibat pandemic Covid-19, sehingga dengan pembekalan dan pelatihan yang diberikan dapat meningkatkan kualitas sumber daya manusia yang ada di SMA Negeri 1 Dolok Batu Nanggar. bantuan sarana dan prasarana sangat dibutuhkan oleh SMA Negeri 1 Dolok Batu Nanggar. Alumni juga sebagai stackholder menyepakati bahwasanya dari diskusi bersama ini akan membantu perkembangan SMA Negeri 1 Dolok Batu Nanggar semaksimal mungkin demi mewujudkan pendidikan di SMA Negeri 1 Dolok Batu Nanggar semakin lebih baik dan menghasilkan alumni-alumni yang bisa dibanggakan suatu saat nanti.

Mendiskusikan Pelatihan dipimpin langsung oleh ketua Tim dalam memberikan metode pembelajaran yang berbeda yang dapat di terapkan kepada siswa/i di sekolah. Pelatihan yang dilakukan diharapkan mampu memberikan edukasi kepada para guru supaya tidak melupakan nilai-nilai yang harus dilakukan disetiap kegiatan belajar mengajar yang akan dilakukan seperti mengucap salam, berdoa, menyanyikan lagu bernuansa Nasionalisme dan nilai-nilai Pancasila ditengah-tengah kehidupan bermasyarakat. 


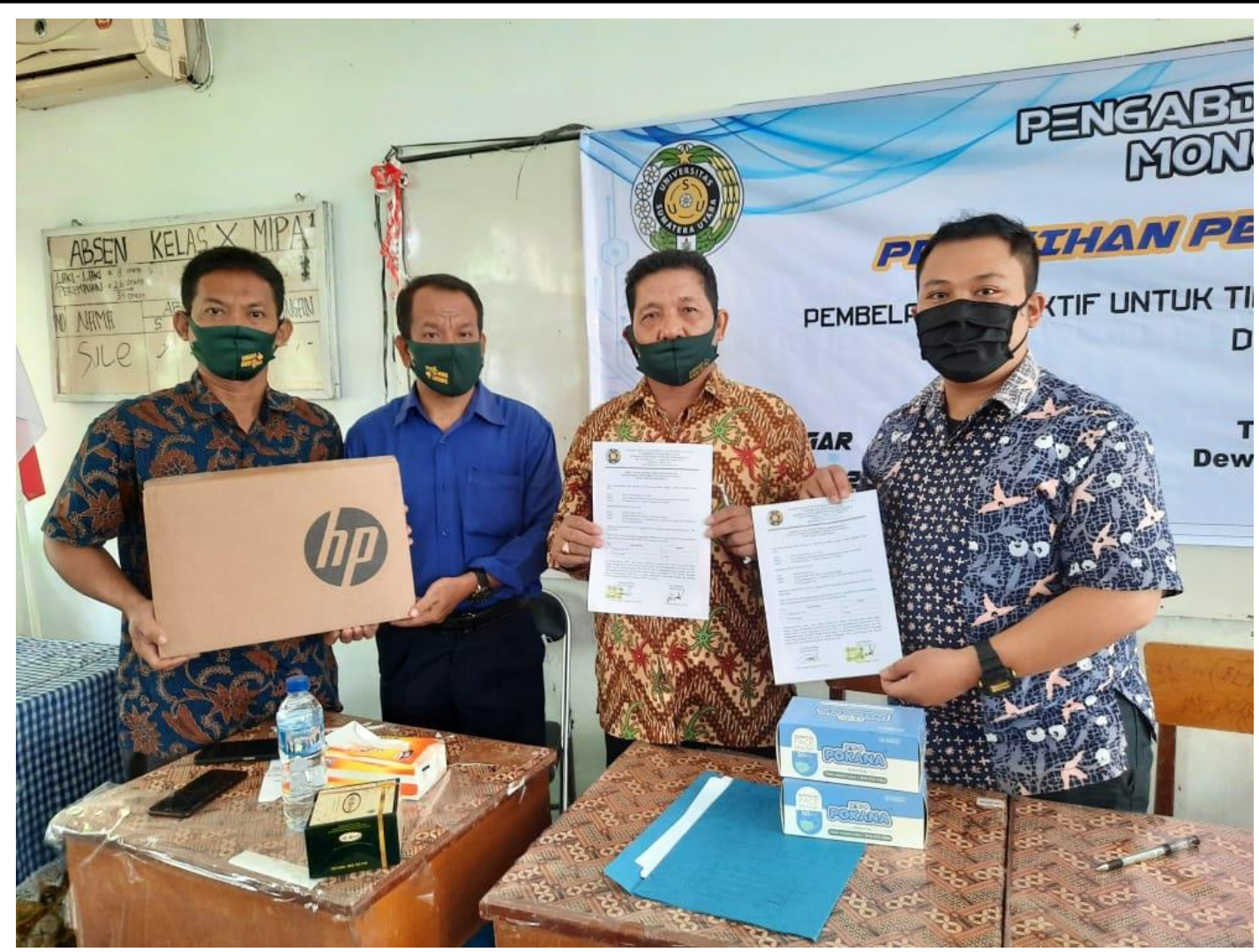

Gambar 4.1. Serah Terima Perangkat Pendukung Pembelajaran Aktif di Sekolah

Selanjutnya dilakukan serah terima perangkat pendukung dalam menciptakan pembelajaran aktif di sekolah kepada Kepala Sekolah SMA Negeri 1 Dolok Batu Nanggar yaitu berupa 1 set Laptop, seminar kit, masker, dan modul pelatihan pembelajaran secara daring. Seluruh perangkat diberikan guna mendukung peran sekolah di dalam menciptakan suasana pembelajaran baru dengan mengedepankan keaktifan siswa/i di dalam lingkungan sekolah.

Harapan dari pemberian bantuan sarana ini yaitu SMA Negeri 1 Dolok Batu Nanggar dapat membantu staf dan guru untuk kegiatan di sekolah terutama kegiatan belajar mengajar. Dan juga siswa dapat menikmati fasilitas yang memang diperlukan oleh mereka dan menambah semangat belajara setiap siswa/i SMA Negeri 1 Dolok Batu Nanggar. 


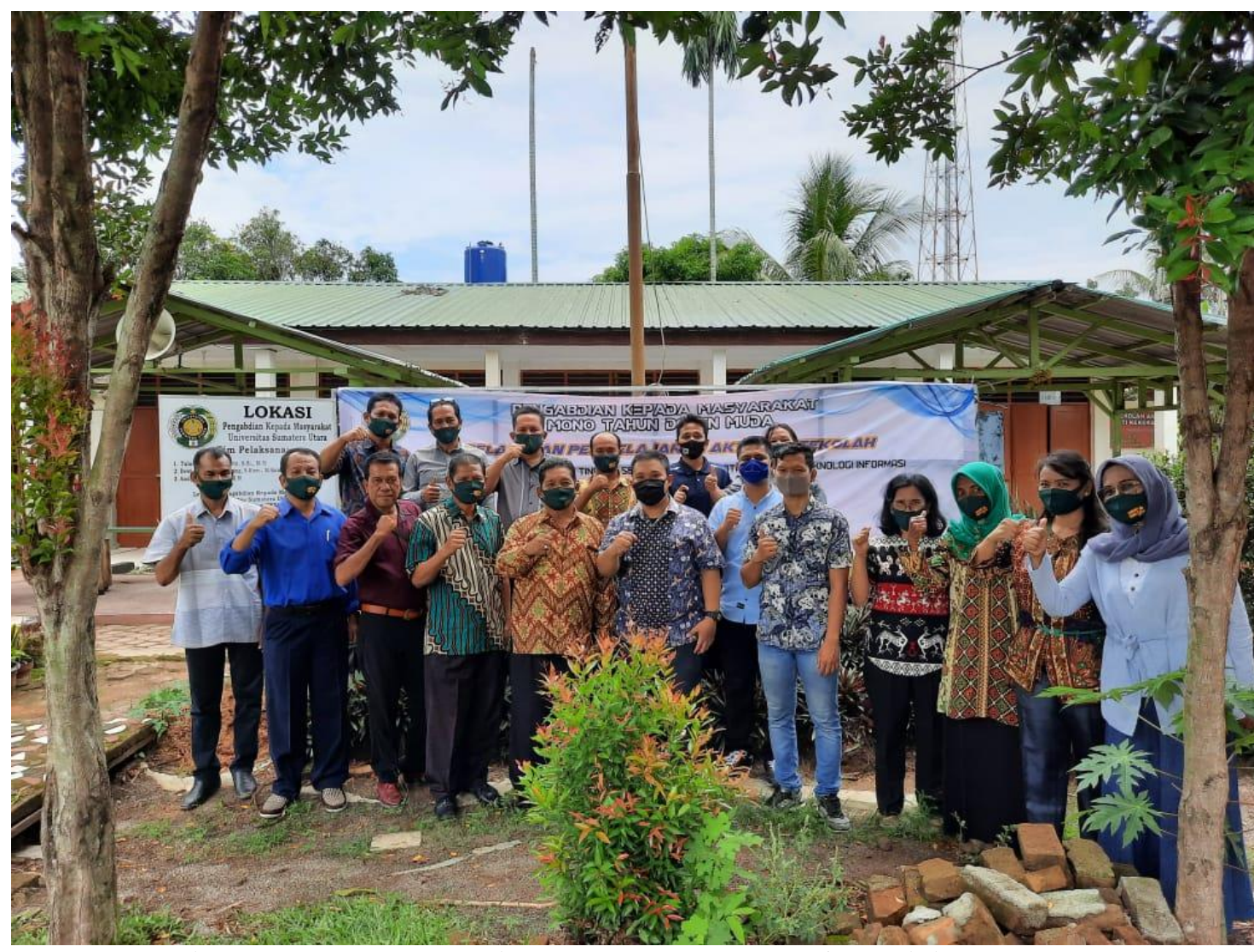

Gambar 4.2. Foto Bersama dengan Guru SMA Negeri 1 Dolok Batu Nanggar

\section{KESIMPULAN}

Pelaksanaan Pengabdian kepada Masyarakat ini telah memberikan beberapa poin penting yang menjadi catatan dalam tulisan ini, yaitu:

1. Dari semua kegiatan pengabdian kepada masyarakat yang dilakukan dapat disimpulkan bahwa kegiatan ini sangat penting dilakukan karena banyak hal positif yang dihasilkan. Dari kegiatan pertama yaitu Diskusi Bersama diperoleh banyak masukan dan saran dalam memperbaiki keadaan pendidikan di Indonesia. Tetapi banyak hambatan yang membuat setiap saran dapat terlambat dalam pelaksanaanya. Sarana dan prasarana yang kurang memadai dalam melakukan kegiatan belajar dan mengajar. Serta keterlibatan alumni dalam membantu membangun dan mengembangkan SMA Negeri 1 Dolok Batu Nanggar.

2. Pemberian materi pembelajaran aktif serta pemberian sarana pembelajaran sesuai hasil Diskusi Bersama dapat dilihat keinginan untuk mengembangkan sekolah sangat tinggi. Dapat dilihat dari keinginan belajar guru dan staf supaya dapat menerapkan pembelajaran aktif di SMA Negeri 1 Dolok Batu Nanggar. Dan dilanjutkan kegiatan ketiga yaitu pemberian materi untuk menerapkan pembelajaran aktif berbasis teknologi informasi dan komunikasi untuk menyempurnakan pembelajaran aktif berbasis TIK. 


\section{UCAPAN TERIMAKASIH}

Artikel ini merupakan salah satu hasil dari Program Pengabdian kepada Masyarakat yang Dibiayai oleh dana NON PNBP Universitas Sumatera Utara dengan nomor 291/UN5.2.3.2.1/PPM/2020. Oleh karena itu, diucapkan terima kasih kepada Rektor Universitas Sumatera Utara atas dukungan dana dan fasilitas yang diberikan. Terima kasih juga kepada Mitra pada kegiatan pengabdian ini.

\section{DAFTAR PUSTAKA}

HomeEdition. 2005, Macromedia flash Profesional 8 help, Macromedia Inc

Juhaeri. 2009. Pengantar Multimedia untuk Media Pembelajaran bagian I, Ilmu Komputer.

Retno, Margono dan Bambang Eka Purnama. ISSN 1979 - 9330. Study of Interaktif Recognition Letter and Number For Children With Computer Multimedia. Indonesian jurnal on Computer Science - Speed (IJCSS) 4 Vol. 3 Nomor 1 Agustus 2008

Script Island. 2008. Panduan Mudah Membuat Animasi. Jakarta: Media Kita.

Tulus, Sawaluddin, T.J. Marpaung, dan M.R. Syahputra. 2018. Making Learning Teaching Materials in School Based On Information And Communication Technology. Abdimas Talenta. Vol. 3 No. 2 pp. 202-2016 